\title{
Donor-specific HLA Antibodies in Solid Organ Transplantation: Clinical Relevance and Debates
}

\author{
Jin Wang ${ }^{1,2, \#^{*}}$, Ping Wang ${ }^{1, \#}$, Shuiliang Wang ${ }^{1, \#}$ and Jianming Tan ${ }^{1 *}$ \\ ${ }^{1}$ Organ Transplant Institution, Fujian Provincial Key Laboratory of Transplant Biology, Fuzhou General Hospital, \\ Xiamen University, Fujian Province 361005, P. R. China; ${ }^{2}$ Department of Epidemiology, School of Public Health, \\ Sun Yat-sen University, Guangzhou 510275, P. R. China; ${ }^{\#}$ These authors contributed equally to this work.
}

\begin{abstract}
Early outcomes following solid organ transplantation have markedly improved in recent years. Antibody-mediated rejection caused by donor specific anti-human leukocyte antigen antibodies (HLA-DSA) is widely recognized to be a risk factor for rejection episode, graft loss and decreased graft survival. The presence of HLA-DSA before transplantation and the appearance of these antibodies after transplantation can induce a wide spectrum of allograft injuries, ranging from the absence of allograft lesions with normal biopsy histopathologies to indolent subclinical processes to acute rejection with early allograft loss. However, the interpretation of the current DSA results is not easy and has led to many discussions and controversies. Current challenges exist in identification of pathologic DSA, monitoring and diagnostic algorithms, appropriate risk stratification, minimization for preformed or de novo DSA by proper use of immunosuppression. This article summarizes recent advances concerning the impact of preformed and de novo DSA in solid organ transplantation, with a focus on the clinical significance of DSA and available treatment modalities. Areas requiring further investigation are also identified.
\end{abstract}

Introduction

Despite all advances in the development of effective immunosuppressive regimens in transplantation, graft rejection plays an increasingly critical role in graft dysfunction and eventual loss of the allograft. The contribution of both acute cellular rejection and antibody-mediated rejection (AMR) episodes has been increasingly recognized. The pathologic impact of donor-specific antibodies (DSA; alloantibodies specifically directed against donor human leukocyte antigens (HLA)) was subsequently widely recognized not only in kidney but also in heart, liver, pancreas, intestine and lung transplantation. ${ }^{1-5}$ Presence of HLA-DSA before transplantation and the marked increase over time in detection of DSA post-

Keywords: Donor specific antibody; Transplantation; Antibody-mediated rejection. Abbreviations: AMR, antibody-mediated rejection; $\mathrm{CDC}$, complement-dependent cytotoxicity; CNI, calcineurin inhibitor; DSA, donor-specific antibodies; FCXM, flow cytometric crossmatch; HLA, human leukocyte antigens; HR, hazard ratio; Ig immunoglobulin; IL, interleukin; IVIG, intravenous immunoglobulin; MFI, mean fluorescence intensity; mTOR, mammalian target of rapamycin; NK, natural killer; $\mathrm{OR}$, odds ratio; SAB, single-antigen bead; Tregs, $\mathrm{CD} 4+\mathrm{CD} 25^{\text {high }}$ cells.

Received: May 16, 2019; Revised: September 12, 2019; Accepted: September 16, 2019

"Correspondence to: Jianming Tan and Jin Wang, Organ Transplant Institution, Fujian Provincial Key Laboratory of Transplant Biology, Fuzhou General Hospital, Xiamen University, Fuzhou 350025, P. R. China. E-mail: tanjm156@xmu.edu.cn; jeanwang0626@163.com

How to cite this article: Wang J, Wang P, Wang S, Tan J. Donor-specific HLA Antibodies in Solid Organ Transplantation: Clinical Relevance and Debates. Exploratory Research and Hypothesis in Medicine 2019;4(4):76-86. doi: 10.14218/ ERHM.2019.00012. transplantation are significantly associated with acute or chronic graft rejection as well as active pathological findings for antibodymediated injury. ${ }^{6,7}$ As a result, monitoring of DSA is becoming increasingly accepted as standard-of-care in transplant recipients. ${ }^{8,9}$ Effective strategies have been adopted to minimize the deleterious effects of AMR by prevention of DSA production and reasonable selection of adequate immunosuppressive regimens.

The aim of the present review is to describe the incidence of anti-HLA-DSA after solid transplantation, and to illustrate their clinical significance and pathologic correlations by exploring recent improvements and controversies. Insights into the management of patients with preformed or post-transplant de novo DSA and recommendations for future research of DSA in transplantation are also within the scope of this review.

Both preformed and de novo DSA represent a significant obstacle to transplantation

\section{Preformed DSA before transplantation}

Exposure to "non-self" HLA molecules, as after blood transfusion, pregnancy or sensitization events, can lead to the development of preformed anti-HLA antibodies. ${ }^{10}$ Transfusion avoidance or the use of HLA-matched blood may reduce this risk and improve outcomes. ${ }^{10}$ Pre-existing sensitization to HLA-DSA may be a contraindication to transplantation due to the increased risk of acute rejection, delayed graft function, and decreased graft survival. ${ }^{11-15}$ In support of this observation, pre-transplant DSA significantly 
increased the risk for AMR and kidney allograft failure by $76 \%$, despite a negative flow cytometry crossmatch result. ${ }^{16}$

Musat et al., ${ }^{17}$ investigating 113 consecutive adult liver transplant recipients, found an association between pretransplant DSA and AMR (anti-class-I, hazard ratio (HR) $=2.7, p<0.01$; anti-classII, HR $=6.0, p<0.01)$. Also, another study showed that in kidney transplant recipients with negative cytotoxicity crossmatches, the presence of class II DSA at the time of transplantation, especially with high strength, was associated with an augmented risk of AMR occurrence. ${ }^{18}$ An analysis of 1,270 liver transplant recipients showed an association between pretransplant DSA intensity and recipient survival. ${ }^{19}$ Strong HLA-DSA levels at baseline were found to be associated with worse allograft outcomes even after successful desensitization. ${ }^{20}$

Although a definite clinical relevance of DSA has been found, unfavorable clinical outcomes are confirmed in some but not all DSA-positive patients. In a large retrospective study, AMR occurred in only $2 \%$ kidney recipients, who had at least one strong DSA with an mean fluorescence intensity (MFI) value greater than $6,000 .{ }^{21}$ Taner et al. ${ }^{22}$ found that preformed DSA disappeared in $85 \%$ of liver transplant recipients after transplantation, and only persistent DSA with high MFI values were responsible for AMR, suggesting that preformed DSA are deleterious to graft survival only when they persist after transplantation. ${ }^{23}$ Thus, some researchers dispute that preformed DSA are likely problematic only when these antibodies remain positive after transplantation and above a certain threshold. ${ }^{24}$ Regardless, the occurrences of AMR, once happened, most often lead to graft loss or serious consequences. Thus, it is important to detect the presence and levels of HLA-DSA before transplantation for accurate assessment of a patient's immunological risk.

\section{De novo DSA post-transplantation}

The antibodies that do not preexist but develop after transplantation and are directed against foreign graft HLA are considered as de novo anti-HLA DSA. Extensive studies in the past have evaluated the prevalence of DSA after transplant and their clinical relevance in terms of risk of acute or chronic rejection. The average annual incidence of de novo DSA varies in a wide range post-transplant. Approximately $10-30 \%$ of heart transplant recipients developed de novo DSA (predominantly anti-HLA class II) after transplantation. ${ }^{25}$ Everly et al. ${ }^{26}$ reported that $11 \%$ of the patients without DSA at the time of renal transplantation would have detectable DSA 1 year later, and the incidence of de novo DSA would increase to $20 \%$ over the next 4 years. Wiebe et al. ${ }^{27}$ found that the mean time to appearance of de novo DSA was 4.6 years post-transplant in $15 \%$ of renal recipients. In a retrospective analysis of 505 patients, Willicombe et al. ${ }^{28}$ reported a rate of de novo production of DSA in $18.2 \%$ of patients, with the mean time to detection of DSA of $9.98 \pm 12.48$ months after kidney transplantation. Likewise, $32 \%$ of previously non-sensitized kidney recipients developed de novo DSA as reported in the study by Gingu et al. ${ }^{29}$

Once de novo DSA appears, the probability of graft loss within 3 years in primary kidney transplantation is $24 \%{ }^{26}$ The independent risk factors that have been identified to develop de novo DSA have included female sex of the recipient, young age of the recipient, viral infection (especially cytomegalovirus and Epstein-Barr virus), class II HLA mismatching, prior cellular rejection, sensitizing events (blood transfusion, retransplantation, pregnancy, etc.) and non-adherence to immunosuppressant medication. ${ }^{27,30-34}$ Also, nephrectomy is considered as a factor that facilitates produc- tion of DSA; while tacrolimus concentration $\geq 3 \mathrm{ng} / \mathrm{mL}$ is protective against the development of allosensitization and can facilitate retransplantation. ${ }^{35}$

Development of de novo DSA post-transplant has been reported to be associated with AMR, increased risk of graft loss and poor transplant outcomes. ${ }^{36,37}$ A recent study showed that the production of de novo DSA after liver transplantation was an independent risk predictor $(\mathrm{HR}=1.85, p=0.01)$ of graft loss in a multivariable model. ${ }^{38}$ Piazza et al. ${ }^{39}$ prospectively screened 120 non-presensitized kidney transplant recipients, and $24.2 \%$ developed DSA at 1 year following transplantation. Patients with positive HLA-DSA had a higher incidence of acute rejection episodes $(62 \%$ vs. $13 \%$, $p<0.001)$, greater probability of allograft failure (34\%vs. $1 \%$, $p<0.001)$, and higher serum creatinine levels $(2.5 \pm 1.3 v s .1 .7$ $\pm 0.5 \mathrm{mg} / \mathrm{dL}, p=0.04$ ) at 2 years after transplantation compared with those patients without DSA. O'Leary et al. ${ }^{40}$ reported that, in 749 liver transplant recipients without any preformed DSA, the formation of de novo DSA led to a higher risk of death (HR 1.8, $p$ $=0.007)$. Support for these findings came from a study by Wiebe et al. ${ }^{27}$ which showed that patients who developed de novo DSA were twice as likely to have clinical rejection within the first 6 months post-kidney transplant, which in turn preceded de novo DSA development.

A recent study of 315 low-risk renal transplant recipients demonstrated that appearance of de novo DSA was the strongest predictor of graft loss (odds ratio $(\mathrm{OR})=6.4, p<0.01$ ), resulting in a $40 \%$ decrease in 10 -year graft survival. ${ }^{27}$ For heart transplantation, circulating class II DSA after transplantation increased the risk of future pathologic AMR $(\mathrm{HR}=2.97) .{ }^{41} \mathrm{Also}$, heart transplant recipients with de novo DSA had a three-fold increased risk of mortality. ${ }^{42}$ Clinical manifestations vary among organs and include acute/ chronic graft dysfunction arising from microvascular injury and/ or progressive tissue fibrosis. Biopsies, even in stable grafts with DSA, reveal microvasculature injury ${ }^{43}$ De novo DSA dramatically accelerate post-transplant progression of arteriosclerosis, roughly three times faster, in DSA-positive patients compared with DSAnegative patients. ${ }^{44}$ DSA have been reported to play a role in inflammation and fibrosis formation. ${ }^{45-48}$ Miyagawa-Hayashino et $a l .{ }^{49}$ evaluated 79 pediatric liver transplant recipients with protocol liver biopsies and detected DSA in 32 individuals (48\%); these patients had a higher frequency of bridging fibrosis or cirrhosis $(88 \%)$ than the DSA-negative patients $(17 \%)$ did.

It seems that the earlier de novo DSA appear, the worse the outcome is. Kasahara et al. ${ }^{50}$ demonstrated that once liver transplant recipients developed DSA detected by flow cytometry crossmatch within the first month after transplant, $100 \%$ experienced acute rejection episodes, as compared to an incidence of only $17.4 \%$ in DSA-negative recipients. It is reported that antibodies which are developed within a year after kidney transplantation can result in graft failure in a mean time of 5.1 years. In contrast, antibodies, which are formatted after the first year, are associated with a slow rate of failure, and $80 \%$ of patients have functional grafts one decade after transplantation. ${ }^{51}$ It is possible that antibodies formed within the first year react rapidly on the endothelium, initiating a cascade of events that lead to rejection. In the light of these observations, protocol biopsies are helpful to facilitate an early diagnosis for chronic AMR, at least in patients who develop DSA within the first post-transplant year. Interestingly, the presence of de novo DSA within the first post-transplant year but cessation of their production in the subsequent years predicts a good prognosis regarding long-term allograft function and survival. ${ }^{43}$

Taken together, surveillance for preformed and de novo DSA may predict graft dysfunction and clinical outcomes even in those low immunologic risk patients. From this point, it seems that all 


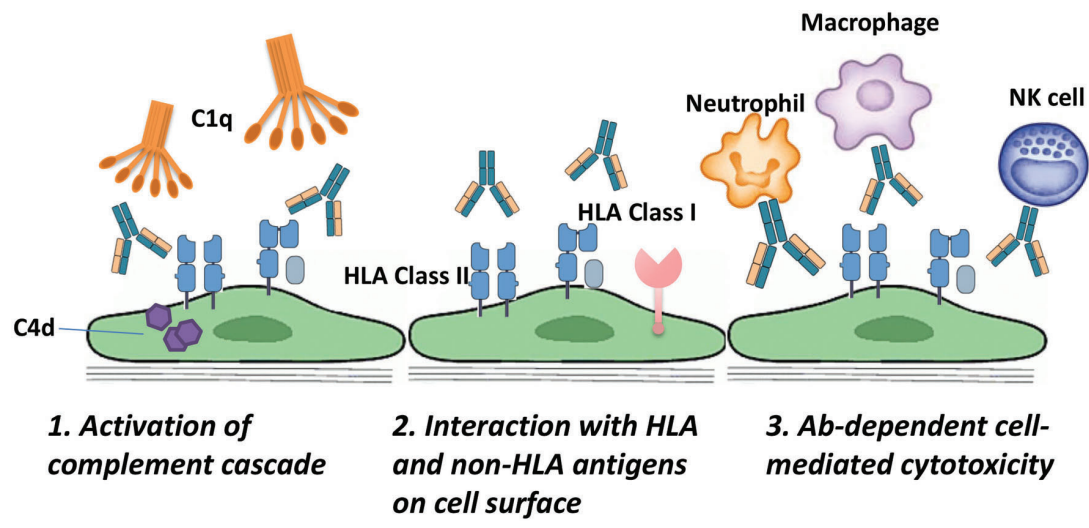

Fig. 1. The main mechanisms underlying DSA-mediated graft damage. There are at least three mechanisms: (1) activation of classical complements; (2) direct and indirect damage to vascular endothelium through their interactions with HLA and/or non-HLA antigens expressed on cell surface; and (3) antibodydependent cell-mediated cytotoxicity. Abbreviations: DSA, donor-specific antibodies; HLA, human leukocyte antigens.

patients need to be monitored for DSA to identify the time, interval of DSA onset, DSA strength or clearance. ${ }^{52}$

\section{Mechanisms by which DSA induce graft damage}

The main mechanisms by which DSA mediate graft damage include ${ }^{53-58}$ : (1) complement activation via the classical pathway and the resultant formation of the membrane attack complex, as evidenced by the presence of $\mathrm{C} 1 \mathrm{q}, \mathrm{C} 4 \mathrm{~d}$ and $\mathrm{C} 3 \mathrm{~d}$ at the site of complement activation ${ }^{59} ;(2)$ direct and indirect damage to vascular endothelium through their interactions with HLA and/or non-HLA antigens expressed on cell surface; and (3) activation of proinflammatory cells such as natural killer (NK) cells, macrophages and neutrophils, which are involved in inducing injury of vascular endothelium (Fig. 1). ${ }^{60,61}$

The classical complement pathway is activated by binding of the globular domains of C1q with immunoglobulin (Ig)G or IgM bound to antigen epitopes on the graft endothelium..$^{62}$ Once activated by $\mathrm{C} 1 \mathrm{q}$, the classical complement cascade leads to the generation of the key effector molecules of the complement system, the terminal membrane attack complex which causes cell lysis. As complement activation initiated by $\mathrm{C} 1 \mathrm{q}$ crosslinking of $\mathrm{IgG}$ bound to the allograft, it is hypothesized that DSA with high capability of binding Clq may confer the highest risk of graft injury.

Yabu et al. ${ }^{63}$ were the first to report the clinical significance of C1q-positive de novo DSA in adult kidney transplant recipients. They found that DSA testing with C1q assay had higher levels of specificity for transplant glomerulopathy and graft loss than testing with the standard IgG DSA assay. The appearance of C1q-positive DSA was associated with substantially worse pathology and clinical outcomes in comparison with C1q-negative DSA. ${ }^{40,64,65}$ In a study of 1,016 renal transplant recipients, patients with C1q-positive DSA had the poorest 5-year graft survival after transplantation (54\%), as compared with patients with non-C1q-positive DSA and patients without DSA (93\% and 94\%, respectively). ${ }^{66}$ Also, patients who developed de novo C1q-binding DSA after transplantation had the highest risk of graft loss. ${ }^{66} \mathrm{~A}$ study has showed that circulating $\mathrm{C} 1 \mathrm{q}$ DSA are a strong and independent predictor of response to treatment in kidney recipients with AMR. ${ }^{67}$ Thus, patients with strong DSA and C1q-positive DSA are considered at greatest risk of graft loss and should be closely monitored for DSA persistence after transplantation. ${ }^{68}$

$\mathrm{C} 4 \mathrm{~d}$ is an important component of the complement cascade, and thus is considered as a marker of complement regulation. Detection of DSA together with typical C4d deposition along renal peritubular capillaries was thought of as the gold standard technique to detect complement activation. ${ }^{69}$ The presence of DSA in serum samples obtained at the time of for-cause biopsies is strongly correlated with histological findings, including microvascular inflammation, intragraft C4d staining, transplant glomerulopathy, interstitial inflammation and tubulitis. ${ }^{70}$ Thus, appearance of DSA, $\mathrm{C} 4 \mathrm{~d}$ deposit, and microvascular injury may represent great risk for hemodynamic instability, graft dysfunction, and ultimately graft failure.

Despite the widespread use of C4d staining in the clinical management of transplant recipients, over time it has been realized that C4d is neither completely specific nor sufficiently sensitive for the diagnosis of AMR. ${ }^{71}$ C4d-negative kidneys may share features of antibody-mediated injury. A study showed that, of the biopsies, $55 \%$ of C4d-negative biopsies had evidence of concomitant microvascular injury. ${ }^{72}$ Data have revealed a high endothelial-specific gene expression in biopsies from kidney transplant recipients with DSA but who are negative for $\mathrm{C} 4 \mathrm{~d}$, indicating ongoing antibodymediated injury even without impact of $\mathrm{C} 4 \mathrm{~d}$ activation. ${ }^{73}$ Despite $\mathrm{C} 4 \mathrm{~d}$ staining indeed a useful tool in identifying patients at great risk of unfavorable clinical outcomes, it alone may not be sensitive enough to establish a diagnosis of acute AMR.

In addition to complement-dependent mechanisms, experimental evidence has demonstrated that antibody-mediated damage against the graft may occur in the absence of complements through antibody-dependent cell cytotoxicity and/or direct activation of endothelial cells. ${ }^{74-76}$ Antibody-dependent cell cytotoxicity involving $\gamma \delta \mathrm{T}$ cells or NK cells contributes to DSA-mediated graft injury. ${ }^{60}$ It is known that inflammatory events may lead to increased interferon levels, which induce an up-regulation of MHC expression on endothelial cells and stimulate B-cells and plasma cells to produce DSA. DSA are capable of inducing injury of vascular endothelium through recruitment of neutrophils, macrophages, or NK cells. Circulating DSA, even at a low concentration or undetectable by the single-antigen bead (SAB) assay, might be retained on the graft endothelium and stimulate NK cells via CD16. ${ }^{77}$

Activated endothelial cells, through production of cytokines and chemokines like interleukin (IL)-1 $\alpha$, IL-8, and monocyte chemotactic protein-1 (commonly known as MCP-1) to recruit neutrophils and monocytes to the graft site, initiate and promote graft rejection together with their interactions with platelet and mononuclear cells. Interestingly, CD4+CD2 $5^{\text {high }}$ cells (Tregs) display a protec- 
tive role against DSA development during the first post-transplant year in kidney transplant recipients. Alberu et al. ${ }^{78}$ prospectively studied a cohort of unsensitized renal transplant recipients before transplant and quantified the numbers of peripheral blood Tregs at different time points during the first post-transplant year. The temporal relationship was observed between peripheral Treg number and production of de novo DSA. DSA-negative patients with better outcomes had significantly higher numbers of Tregs at 12 months after kidney transplantation, reflecting better immune acceptance of the graft. Other experimental data has also shown that a small amount of rapamycin could synergize with alloantigen to activate Tregs, permitting the achievement of specific clinical transplantation tolerance and long-term heart graft survival in an immunocompetent mouse. ${ }^{79}$ A further understanding of the underlying mechanisms of DSA in AMR episodes is, thus, of key importance for improving risk stratification and therapeutic strategies.

\section{Detection of DSA with novel techniques}

Patel and Terasaki published their landmark study in $1969,{ }^{80}$ which revealed the detrimental effect of preformed DSA on short-term allograft survival, as detected by complement-dependent cytotoxicity (CDC) crossmatch with a limited sensitivity. Since that time, more sensitive solid-phase assays based on enzyme-linked immunosorbent assay (commonly known as ELISA), flow cytometry and Luminex ${ }^{\circledR}$ platforms have been introduced for detection and specification of DSA. ${ }^{81}$ Flow cytometric crossmatch (referred to FCXM) is a cell-based assay for detecting antibodies that bind to the surface of donor lymphocytes, and this technique is more sensitive than CDC. It is sensitive but cannot differentiate complement fixing antibodies from non-complement fixing antibodies. SAB technology enables the identification of antibodies that bind to individual HLA allelic variants with high sensitivity and specificity. ${ }^{82}$ Luminex$\mathrm{SAB}$ is able to detect the presence of DSA in patients with negative crossmatch or in patients with conversion to a negative crossmatch after desensitization. ${ }^{83,84}$ But this method is less predictive of transplant outcome and less clinically relevant, since it detects both complement-binding (often regarded as pathogenic antibodies) and non-complement fixing anti-HLA antibodies.

The reported MFI values determining the border between positive and negative reactions differs between centers and amongst studies. ${ }^{85,86}$ It has been indicated that transplantation with a threshold of MFI of 500 or less is of the greatest benefit and cost-saving in those without preformed DSA. Increasing the threshold to an MFI of 2,000-5,000 may provide an acceptable balance for improving transplant eligibility of the listed patients but incurs increased risk of acute rejection and long-term graft failure, even if the CDC crossmatch is negative. ${ }^{87}$ In view of the different methods with their own advantages, a reasonable method of risk stratification prior to transplant has been suggested as the following sequence of immunologic testing: CDC crossmatch followed by Luminex$\mathrm{SAB}$ for DSA identification and then using flow crossmatch testing only if further stratification for risk of AMR is desired. ${ }^{16}$

\section{Specificity and strength of DSA}

\section{Specificity of DSA}

The main effect of DSA ultimately depends on its specificity and strength. Class I and II DSA have their own features in timing and frequency of appearance and clinical significance. It has been reported that HLA class I DSA are produced sooner (median time to detection 6.6 months) and are associated with rapid graft loss; while, class II DSA occur later (median time to detection 12.5 months) and may be associated with chronic transplant glomerulopathy. ${ }^{51}$ In renal transplantation, DSA against HLA class II antigens are more common than class I and represent $95 \%$ of all $d e$ novo DSA, demonstrating the importance of HLA class II incompatibility. ${ }^{38}$ Patients with both class I and II DSA or even class II alone are at the greatest risk for chronic AMR, with anti-DQ de novo DSA being the predominant specificity in kidney, liver, heart and lung transplant patients. ${ }^{28,38,88-90}$ Most of the performed class I DSA (94\%) change to negative at 1 year after kidney transplantation. Unlike class I DSA, preformed class II DSA with higher MFI are more commonly persistent after transplantation (77\%). ${ }^{91}$

O'Leary et al. ${ }^{19}$ reported that strong preformed class I DSA (MFI $>5,000)$ remained positive in only $5 \%$ of liver transplant recipients after transplantation and were not associated with rejection episodes. In contrast, strong preformed class-II DSA (MFI > $5,000)$ remained persistent in $23 \%$ of patients and were an independent predictor for early rejection. Most patients with preformed class I DSA alone at low or moderate levels are unlikely to have severe short- or long-term consequences in liver transplantation. ${ }^{2}$ The liver is capable of eliminating or neutralizing HLA antibodies, particularly class I antibodies, which may in part account for its tolerogenic properties. ${ }^{22,92}$ Thus, DSA class II-incompatible graft transplantation needs careful monitoring and should be avoided in those patients with high immunological risk. ${ }^{93}$ It is necessary to bring class II matching to a higher level such as epitope matching, in order to further minimize de novo DSA development. ${ }^{94}$

Antigen mismatches are associated with anti-HLA-DQ DSA. DQ molecules are the principal stimulators of de novo DSA in non-sensitized renal transplant recipients and these antibodies may contribute to inferior graft outcomes. ${ }^{88,95}$ Previous studies have demonstrated that donor-specific HLA-DQ antibodies were the most commonly detected type, which may be associated with unfavorable outcomes after renal and cardiac transplantation. ${ }^{96,97}$ DQ antibodies individually, particularly those expressed at higher MFIs $(>13,000)$, have been shown to result in inferior graft outcomes, as compared with results from patients without DSA, ${ }^{98}$ suggesting that patients with de novo DQ-DSA development may require similar interventions as those with de novo-A, -B and -DR antibodies.

Willcombe et al. ${ }^{28}$ demonstrated a strong association between mismatching at the DR/DQ loci and subsequent risk for DQ-DSA development, AMR, and graft loss. To be noted, most clinical studies have focused on antibodies against class I HLA-A and -B and class II HLA-DR and -DQ rather than against class I HLA-C and class II HLA-DP. The clinical implications of anti-HLA-C and -DP antibodies in the context of transplantation are less significant because these antigens are expressed at lower levels than other HLA antigens. In fact, patients with preformed HLA-C and -DP DSA appear to be at high risk for the occurrence of AMR. ${ }^{99,100}$ Screening of these antibodies is therefore necessary, and modulation of immunosuppression is perhaps required in cases of positivity.

\section{Strength of DSA}

High-MFI has been suggested as a determinative factor for worse graft outcomes. ${ }^{101}$ Preformed DSA with a high MFI that persist after liver transplantation are associated with severe early rejection and graft loss. ${ }^{102}$ A multivariate model has showed that in comparison with no or weak DSA (MFI $<1,000)$, preformed class I and/or 
II DSA with an MFI of 5,000 in liver transplantation are independently correlated with risk of death $(\mathrm{HR}=1.51, p=0.02) .{ }^{19}$ Strong HLA-DSA level $(\mathrm{MFI}>10,000)$ at baseline has been reported to be predictive of an increased risk of AMR and decreased long-term allograft survival in liver transplantation. ${ }^{103}$ In a receiver operating characteristic curve analysis, the cut-off MFI value of 4,487 for class II DSA at the time of kidney transplantation predicted the occurrence of AMR with good sensitivity $(100 \%)$ and specificity $(87.0 \%) .{ }^{18}$

Findings in our center also demonstrated that DSA-positive renal transplant recipients who developed an acute rejection episode had a higher cumulative MFI value $(8,118.3 \pm 5,287.4$; range, $1,785-14,985)$ than patients who did not develop an acute rejection episode $(3,283.7 \pm 2,601.0$; range, $786-8,113 ; p<0.05)$, suggesting that patients with de novo DSA at high strength might suffer a high risk of developing an acute rejection episode. ${ }^{104} \mathrm{~A}$ study predicting the outcome in kidney transplant recipients showed that 8 -year graft survival rate decreased progressively with increasing peak HLA-DSA level, being $82.5 \%$ in patients with MFI $<465$, $78.4 \%$ with MFI 466-3,000, and $60.6 \%$ with MFI $>3,000(p<$ $0.001){ }^{105}$ Also, patients with MFI $>6,000$ had $>100$-fold higher risk of AMR than patients with MFI $<465$ (relative risk $=113$; 95\% confidence interval: $31-414$ ).

However, controversies still exist regarding the strength of DSA and clinical significance. A few studies have found no association between the level of DSA and the occurrence of AMR. ${ }^{106,107}$ In support of this view, Amico et al. ${ }^{108}$ found that the number, class, and cumulative strength of HLA-DSA determined by SAB were not predictive for the occurrence of AMR. To be noted, since MFI is a semiquantitative way of describing the "strength" of DSA and that it can also be affected by dilutions with EDTA in the process of $\mathrm{SAB}$ analysis, the results of these studies on DSA strength should be generalized with caution.

Several studies have been carried out to clarify the meaning of low MFI and postoperative changes in DSA. The clinical relevance of DSA at low levels is still being debated. The presence of weakly reactive DSA of peak value has been shown to be associated with AMR and poor kidney graft survival. ${ }^{105}$ On the contrary, in another study, compared with DSA-negative patients, patients with weak pretransplant DSA $(<3,000 \mathrm{MFI})$ did not have increased risk of AMR, cellular rejection, or graft loss, suggesting that preformed weak DSA in the setting of a negative FCXM confers minimal immunologic risk. ${ }^{109}$ Thus, it seems that pretransplant DSA at very low level does not necessitate desensitization therapy and should not represent a barrier to renal transplant. Findings from other studies support that under close monitoring and proper use of an immunosuppression regimen, the patients with weak DSA are allowed to be transplanted with outcomes equivalent to those without DSA. ${ }^{110}$

The cut-off MFI value of Luminex assay for predicting the development of acute AMR with acceptable sensitivity and specificity is identified to fall within a wide range of 3,000 to 10,000 , according to findings from among various reports. ${ }^{19,110,111}$ These discrepancies may be partially caused by different techniques for antibody detection used by the various investigators, different methods of DSA calculation, different immunosuppression protocols, sizes and types of the patient populations, and timings and frequencies of sample detection. On the other hand, the difference in clinical impact between a single DSA and multiple DSA remains unclear. Some investigators have used the sum of MFIs but others have used single-peak MFI. Further efforts are needed to standardize these sources of variability in an attempt to resolve the challenges of clinical interpretation when DSA levels are measured.

\section{DSA desensitization}

The early outcomes of recipients with DSA have been satisfactory by sufficient desensitization before transplantation. ${ }^{112}$ Even a case with DSA can be transplanted safely by proper desensitization therapy. The type of treatment in the presence of DSA posttransplantation largely depends on clinical manifestations and histological presentations. In patients with acute or chronic allograft dysfunction, various protocols are used to reduce the amount of circulating DSA. The commonly used protocols include (1) removal of harmful antibodies by plasmapheresis or immunoadsorption and (2) treatment modalities such as intravenous immunoglobulin (IVIG), antithymocyte globulin, anti-CD20 antibody (i.e. rituximab), anti-C5 antibody (i.e. eculizumab), and proteasome inhibitor (i.e. bortezomib), along with calcineurin inhibitor (CNI) and/or mycophenolate mofetil. ${ }^{113-117}$ On the contrary, there is no consensus regarding the treatment of clinically stable transplant recipients with circulating de novo DSA. It is largely unknown how to treat these patients. A closer monitoring of these patients, in addition to maintaining use of immunosuppressive therapy which typically includes tacrolimus and mycophenolate mofetil, is generally suggested.

Plasmapheresis and immunoabsorption techniques have been used to remove various types of alloantibodies. However, repeated treatments or an additional inhibitor of antibody production is usually required, due to the tendency of DSA to rebound. Therapeutic plasma exchange followed by low-dose IVIG has been reported to decrease circulating DSA for pretransplant desensitization, in an attempt to increase donor availability. ${ }^{118,119}$ The treatment reduces DSA levels by $25.3 \%$ and $35.5 \%$ after three and six plasma exchange procedures, respectively. ${ }^{119}$ HLA class I DSA are removed slightly more than class II DSA, with the least reduction rate corresponding to DR-DSA. ${ }^{120}$

In maintenance regimens, early CNI withdrawal is not advisable, especially in those who have absence of depleting induction, which will then cause increased risk of de novo DSA production. ${ }^{121}$ A high variability of tacrolimus level, which reflects exposure to low immunosuppressive drug levels, is reported to be a strong risk factor for de novo DSA development. ${ }^{122,123}$ Interestingly, cyclosporine is considered to be associated with an increased rate of DSA production. ${ }^{38}$ These evidence support strict adherence to immunosuppression and use of tacrolimus rather than cyclosporine for preventing de novo DSA formation. Few data have demonstrated a consistent effect of mycophenolic acid on de novo DSA production. A low dose of mycophenolic acid may be associated with the formation of DSA, and a minimum exposure of $1.3 \mathrm{mg} / \mathrm{L}$ may prevent the formation of DSA. ${ }^{124}$

Early conversion to mammalian target of rapamycin (referred to as mTOR) inhibitor has been reported to increase the risk of developing class II DSA, especially in the presence of DQ mismatches. ${ }^{125}$ In a retrospective study performed by Kamar et al., ${ }^{126}$ a substantially increased incidence of DSA was observed in patients on a CNI-free everolimus-based immunosuppression regimen. A multivariate regression model revealed everolimus, $>3$ mismatches and living donor as significant risk factors for production of DSA. Thus, mTOR inhibitor monotherapy administered early after transplant is not recommended. Additionally, conversion to a CNI-free, everolimus-based regimen should be carefully implemented only in immunological low-risk patients and closely monitoring is needed. ${ }^{127}$

Induction therapy with newer agents, like rituximab or bortezomib, may be of interest for patients at immunological risk. However, the exact benefits are unproven in adequately powered 
studies. Rituximab induction has been reported to be beneficial to desensitize or abrogate rebound antibodies in patients undergoing desensitization for AMR. ${ }^{128}$ Desensitization with IVIG and rituximab resulted in early and sustained DSA removal and a low incidence of acute rejection over a 3 -year post-transplant period in living donor kidney transplant recipients with pretransplant DSA and a positive crossmatch. ${ }^{129}$ Stable lung transplant recipients with early de novo DSA that were treated with IVIG and rituximab achieved similarly good early survival, as compared with their counterparties without DSA. ${ }^{130}$ Bortezomib has been demonstrated to reduce DSA levels by depleting plasma cells in highly sensitized transplant candidates. ${ }^{131}$ In a series of living donor kidney transplants that developed de novo DSA, Everly et al. ${ }^{132} \mathrm{dem}-$ onstrated complete DSA removal in 18 of 26 patients and a $50 \%$ reduction in DSA in an additional seven recipients treated preemptively with bortezomib, but $56 \%$ of the patients with a complete response relapsed after a median of 3.8 months. Using bortezomib in combination with plasmapheresis and rituximab, Woodle et al. ${ }^{133}$ recently found antibody reductions in $86 \%$ of patients, persisting up to 10 months. However, Guthoff et al. ${ }^{134}$ reported that bortezomib alone did not result in a sustained reduction in DSA in sensitized patients awaiting transplant.

Controversy also exists over the use of alemtuzumab (i.e. Campath-1H) in risk of DSA formation. A few studies have demonstrated that alemtuzumab induction immunosuppression is associated with reduced incidence of de novo DSA formation. ${ }^{134}$ However, accumulating evidence shows that alemtuzumab-induced lymphocyte depletion, especially in a CNI-free immunosuppressive regimen, may result in the activation of the humoral response toward alloantigens. Thus, alemtuzumab treatment is associated with an increased risk for the development of de novo DSA and inferior graft function, with an excess risk for early AMR. ${ }^{135}$ Targeting the B-cell compartment by intervention of B-cell-activating factor/proliferation-inducing ligand (commonly known as BAFF/ APRIL) pathway appears to be a novel strategy and has gained considerable interest. Kwun et al. ${ }^{136}$ demonstrated that simultaneous blockade of BAFF and APRIL using a fusion protein (commonly known as TACI-IgFc; atacicept) that might prevent early DSA production and AMR, in a depletion-induced preclinical AMR model. In addition, novel costimulatory blockers, such as T-cell-specific surface glycoprotein CD28 (commonly known as CD28) and cytotoxic T-lymphocyte protein 4 (commonly known as CTLA4-Ig; belatacept) that prevent T-cell help to B-cells may represent an important adjunct to prevent de novo DSA. ${ }^{137}$

\section{Outlook}

DSA have been proven to be associated with acute and chronic allograft rejection. Criteria for acute AMR are nearing consensus agreement, but detection of chronic AMR will likely require additional studies. Chronic AMR is a challenge for diagnosis, because the disease progresses slowly by years, with fluctuating pathology and variable clinical manifestations. Also, not all cases have detectable C4d or DSA at any particular time. So, how to specify single, peak or accumulated DSA strength in combination with detection of complement fixation using $\mathrm{C} 1 \mathrm{q}, \mathrm{C} 4 \mathrm{~d}$, or $\mathrm{C} 3 \mathrm{~d}$ assays in the attempt to improve predictive accuracy for silent chronic AMR deserves further attention from the transplant community.

Although accumulating extensive experimental and clinical evidence shows an association between circulating DSA and potential pathologic manifestations, causation largely remains unclear. HLA-DSA can induce a wide spectrum of allograft injuries, ranging from the absence of allograft lesions with normal biopsy histopathologies to indolent subclinical processes to acute AMR with early allograft loss. ${ }^{138}$ Considering that some patients can do quite well even after developing de novo DSA, it is unclear whether every de novo DSA has equal pathogenicity or some of these antibodies are simply acting as "innocent bystanders". Also, how to differentiate pathogenic versus inert antibodies in different individuals remains unknown. Of course, some detrimental consequences of DSA may be subclinical or remain clinically silent over long periods of time. ${ }^{139}$

It is possible that antibody class, strength, specificity, complement-binding capacity, functional properties, and antigen density and location are determinants for the ultimate clinical outcome. While some DSA+/AMR - biopsies retain normal histopathologies, they do show increased levels of rejection-associated transcripts (whole-blood gene expression), including those related to interferon, T-cell, B-cell, NK cell and macrophage function. ${ }^{138}$ Thus, specific prospective studies addressing immunological risk stratification are required to define the clinical benefit and cost-effectiveness of the comprehensive assessment of HLA-DSA before implementation in current clinical practice.

Long-term transplant outcomes may benefit from routine monitoring for DSA. The challenge, therefore, is to develop a cost-effective DSA monitoring algorithm. However, currently, there is no standard or consensus follow-up protocol for de novo DSA after transplantation. Ideally, all allograft recipients should be tested for DSA prior to transplantation, and positive patients should be retested on a monthly basis post-transplantation to determine persistence. ${ }^{140}$ To be noted, some non-HLA DSA, like, angiotensin-II type-1 receptor (commonly known as AT1R), anti-glutathione-Stransferase T1 (commonly known as GSTT1), MHC class-I related chain A (commonly known as MICA) antibodies, can also induce acute and chronic graft dysfunction, all of which deserve additional attention. ${ }^{141-144}$ Future research is required in the exploration of mechanisms to identify pathologic DSA, development of monitoring and diagnostic tools, appropriate risk stratification, and minimization for de novo DSA by proper use of immunosuppression.

\section{Acknowledgments}

This work was supported by funding from the Natural Science Foundation of Fujian Province of China (No. 2016J01577).

\section{Conflict of interest}

The authors have no financial interests or any conflict of interests to disclose.

\section{Author contributions}

Draft writing (JW, PW, SW), manuscript revising (JT, JW).

\section{References}

[1] McKenna RM, Takemoto SK, Terasaki PI. Anti-hla antibodies after solid organ transplantation. Transplantation 2000;69:319-326. doi:10.1097/00007890-200002150-00001.

[2] O'Leary JG, Demetris AJ, Friedman LS, Gebel HM, Halloran PF, Kirk AD, et al. The role of donor-specific hla alloantibodies in liver transplan- 
tation. Am J Transplant 2014;14:779-787. doi:10.1111/ajt.12667.

[3] Malheiro J, Martins LS, Tafulo S, Dias L, Fonseca I, Beirao I, et al. Impact of de novo donor-specific anti-hla antibodies on grafts outcomes in simultaneous pancreas-kidney transplantation. Transpl Int 2016;29:173-183. doi:10.1111/tri.12687.

[4] Cantarovich D, De Amicis S, Akl A, Devys A, Vistoli F, Karam G, et al. Posttransplant donor-specific anti-hla antibodies negatively impact pancreas transplantation outcome. Am J Transplant 2011;11:27372746. doi:10.1111/j.1600-6143.2011.03729.x.

[5] Cheng EY, Everly MJ, Kaneku H, Banuelos N, Wozniak LJ, Venick $\mathrm{RS}$, et al. Prevalence and clinical impact of donor-specific alloantibody among intestinal transplant recipients. Transplantation 2017;101:873-882. doi:10.1097/TP.0000000000001391.

[6] Kokko KE, Colvin RB. Below the waterline - the danger of de novo donor-specific hla antibodies. Am J Transplant 2012;12:1077-1078. doi:10.1111/j.1600-6143.2012.04016.x.

[7] Chung BH, Kim JH, Choi BS, Park CW, Kim JI, Moon IS, et al. Clinical significance of the presence of anti-human leukocyte antigendonor specific antibody in kidney transplant recipients with allograft dysfunction. Korean J Intern Med 2018;33:157-167. doi:10.3904/ kjim.2016.107.

[8] Caro-Oleas JL, Gonzalez-Escribano MF, Gentil-Govantes MA, Acevedo MJ, Gonzalez-Roncero FM, Blanco GB, et al. Clinical relevance of antihla donor-specific antibodies detected by luminex assay in the development of rejection after renal transplantation. Transplantation 2012;94:338-344. doi:10.1097/TP.0b013e31825ace2c.

[9] Tait BD, Susal C, Gebel HM, Nickerson PW, Zachary AA, Claas FH, et al. Consensus guidelines on the testing and clinical management issues associated with hla and non-hla antibodies in transplantation. Transplantation 2013;95:19-47. doi:10.1097/TP.0b013e31827a19cc.

[10] Hassan S, Regan F, Brown C, Harmer A, Anderson N, Beckwith H, et al. Shared alloimmune responses against blood and transplant donors result in adverse clinical outcomes following blood transfusion post-renal transplantation. Am J Transplant 2019;19:1720-1729. doi:10.1111/ajt.15233.

[11] Kanter Berga J, Sancho Calabuig A, Gavela Martinez E, Puig Alcaraz N, Beltran Catalan S, Avila Bernabeu A, et al. Pretransplant donor-specific hla antibodies detected by single antigen bead flow cytometry: Risk factors and outcomes after kidney transplantation. Transplant Proc 2012:44:2529-2531. doi:10.1016/j.transproceed.2012.09.102.

[12] Gupta A, Murillo D, Yarlagadda SG, Wang CJ, Nawabi A, Schmitt T, et al. Donor-specific antibodies present at the time of kidney transplantation in immunologically unmodified patients increase the risk of acute rejection. Transpl Immunol 2016;37:18-22. doi:10.1016/j. trim.2016.04.007.

[13] Perasaari JP, Kyllonen LE, Salmela KT, Merenmies JM. Pre-transplant donor-specific anti-human leukocyte antigen antibodies are associated with high risk of delayed graft function after renal transplantation. Nephrol Dial Transplant 2016;31:672-678. doi:10.1093/ndt/gfv391.

[14] Malheiro J, Tafulo S, Dias L, Martins LS, Fonseca I, Beirao I, et al. Analysis of preformed donor-specific anti-hla antibodies characteristics for prediction of antibody-mediated rejection in kidney transplantation. Transpl Immunol 2015;32:66-71. doi:10.1016/j.trim.2015.01.002.

[15] Caro-Oleas JL, Gonzalez-Escribano MF, Gentil-Govantes MA, Acevedo MJ, Gonzalez-Roncero FM, Bernal-Blanco G, et al. Influence of donor specific hla antibodies detected by luminex in kidney graft survival: A multivariate analysis. Hum Immunol 2013;74:545-549. doi:10.1016/j.humimm.2013.01.010.

[16] Mohan S, Palanisamy A, Tsapepas D, Tanriover B, Crew RJ, Dube $\mathrm{G}$, et al. Donor-specific antibodies adversely affect kidney allograft outcomes. J Am Soc Nephrol 2012;23:2061-2071. doi:10.1681/ ASN.2012070664.

[17] Musat Al, Pigott CM, Ellis TM, Agni RM, Leverson GE, Powell AJ, et al. Pretransplant donor-specific anti-hla antibodies as predictors of early allograft rejection in abo-compatible liver transplantation. Liver Transpl 2013;19:1132-1141. doi:10.1002/lt.23707.

[18] Song EY, Lee YJ, Hyun J, Kim YS, Ahn C, Ha J, et al. Clinical relevance of pretransplant hla class ii donor-specific antibodies in renal transplantation patients with negative t-cell cytotoxicity crossmatches. Ann Lab Med 2012;32:139-144. doi:10.3343/alm.2012.32.2.139.

[19] O'Leary JG, Kaneku H, Jennings LW, Banuelos N, Susskind BM, Terasa- ki PI, et al. Preformed class ii donor-specific antibodies are associated with an increased risk of early rejection after liver transplantation. Liver Transpl 2013;19:973-980. doi:10.1002/It.23687.

[20] Chung BH, Choi BS, Oh EJ, Park CW, Kim JI, Moon IS, et al. Clinical impact of the baseline donor-specific anti-human leukocyte antigen antibody measured by luminex single antigen assay in living donor kidney transplant recipients after desensitization therapy. Transpl Int 2014;27:49-59. doi:10.1111/tri.12199.

[21] Rafiq MA, de Boccardo G, Schroppel B, Bromberg JS, Sehgal V, Dinavahi $\mathrm{R}$, et al. Differential outcomes in 3 types of acute antibodymediated rejection. Clin Transplant 2009;23:951-957. doi:10.1111/ j.1399-0012.2009.01036.x.

[22] Taner T, Gandhi MJ, Sanderson SO, Poterucha CR, De Goey SR, Stegall $\mathrm{MD}$, et al. Prevalence, course and impact of hla donor-specific antibodies in liver transplantation in the first year. Am J Transplant 2012;12:1504-1510. doi:10.1111/j.1600-6143.2012.03995.x.

[23] Caillard S, Becmeur C, Gautier-Vargas G, Olagne J, Muller C, Cognard $\mathrm{N}$, et al. Pre-existing donor-specific antibodies are detrimental to kidney allograft only when persistent after transplantation. Transpl Int 2017;30:29-40. doi:10.1111/tri.12864.

[24] David-Neto E, Souza PS, Panajotopoulos N, Rodrigues H, Ventura CG, David DS, et al. The impact of pretransplant donor-specific antibodies on graft outcome in renal transplantation: A six-year followup study. Clinics (Sao Paulo) 2012;67:355-361. doi:10.6061/clinics/2012(04)09.

[25] Barten MJ, Schulz U, Beiras-Fernandez A, Berchtold-Herz M, Boeken $\mathrm{U}$, Garbade J, et al. The clinical impact of donor-specific antibodies in heart transplantation. Transplant Rev (Orlando) 2018;32:207-217. doi:10.1016/j.trre.2018.05.002.

[26] Everly MJ, Rebellato LM, Haisch CE, Ozawa M, Parker K, Briley KP, et al. Incidence and impact of de novo donor-specific alloantibody in primary renal allografts. Transplantation 2013;95:410-417. doi:10.1097/TP.0b013e31827d62e3.

[27] Wiebe C, Gibson IW, Blydt-Hansen TD, Karpinski M, Ho J, Storsley $\mathrm{LJ}$, et al. Evolution and clinical pathologic correlations of de novo donor-specific hla antibody post kidney transplant. Am J Transplant 2012;12:1157-1167. doi:10.1111/j.1600-6143.2012.04013.x.

[28] Willicombe M, Brookes P, Sergeant R, Santos-Nunez E, Steggar C, Galliford J, et al. De novo dq donor-specific antibodies are associated with a significant risk of antibody-mediated rejection and transplant glomerulopathy. Transplantation 2012;94:172-177. doi:10.1097/ TP.0b013e3182543950.

[29] Gingu C, Moise A, Constantinescu I, Serbanescu B, Surcel C, Sinescu I. Cytotoxic antibodies monitoring in kidney transplantationtheir clinical relevance and challenges. Rom J Morphol Embryol 2012;53:515-519.

[30] Del Bello A, Congy-Jolivet N, Danjoux M, Muscari F, Lavayssiere L, Esposito $\mathrm{L}$, et al. De novo donor-specific anti-hla antibodies mediated rejection in liver-transplant patients. Transpl Int 2015;28:1371-1382. doi:10.1111/tri.12654.

[31] Godown J, Slaughter JC, Fossey SC, McKane M, Dodd DA. Risk factors for the development of donor-specific antibodies after pediatric heart transplantation. Pediatr Transplant 2015;19:906-910. doi:10.1111/petr.12606.

[32] Ferrandiz I, Congy-Jolivet N, Del Bello A, Debiol B, Trebern-Launay K, Esposito $L$, et al. Impact of early blood transfusion after kidney trans plantation on the incidence of donor-specific anti-hla antibodies. Am J Transplant 2016;16:2661-2669. doi:10.1111/ajt.13795.

[33] Jordan SC, Vo AA. Donor-specific antibodies in allograft recipients: Etiology, impact and therapeutic approaches. Curr Opin Organ Transplant 2014;19:591-597. doi:10.1097/MOT.0000000000000128.

[34] Sawinski D, Forde KA, Trofe-Clark J, Patel P, Olivera B, Goral S, et al. Persistent bk viremia does not increase intermediate-term graft loss but is associated with de novo donor-specific antibodies. J Am Soc Nephrol 2015;26:966-975. doi:10.1681/ASN.2014010119.

[35] Lucisano G, Brookes P, Santos-Nunez E, Firmin N, Gunby N, Hassan $\mathrm{S}$, et al. Allosensitization after transplant failure: The role of graft nephrectomy and immunosuppression - a retrospective study. Transpl Int 2019;32(9):949-959. doi:10.1111/tri.13442.

[36] Ginevri F, Nocera A, Comoli P, Innocente A, Cioni M, Parodi A, et al. Posttransplant de novo donor-specific hla antibodies identify 
pediatric kidney recipients at risk for late antibody-mediated rejection. Am J Transplant 2012;12:3355-3362. doi:10.1111/j.16006143.2012.04251.x.

[37] Wiebe C, Gibson IW, Blydt-Hansen TD, Pochinco D, Birk PE, Ho J, et al. Rates and determinants of progression to graft failure in kidney allograft recipients with de novo donor-specific antibody. Am J Transplant 2015;15:2921-2930. doi:10.1111/ajt.13347.

[38] Kaneku H, O'Leary JG, Banuelos N, Jennings LW, Susskind BM, Klintmalm GB, et al. De novo donor-specific hla antibodies decrease patient and graft survival in liver transplant recipients. Am J Transplant 2013;13:1541-1548. doi:10.1111/ajt.12212.

[39] Piazza A, Poggi E, Borrelli L, Servetti S, Monaco PI, Buonomo O, et al. Impact of donor-specific antibodies on chronic rejection occurrence and graft loss in renal transplantation: Posttransplant analysis using flow cytometric techniques. Transplantation 2001;71:1106-1112. doi:10.1097/00007890-200104270-00017.

[40] O'Leary JG, Kaneku H, Banuelos N, Jennings LW, Klintmalm GB, Terasaki PI. Impact of igg3 subclass and c1q-fixing donor-specific hla alloantibodies on rejection and survival in liver transplantation. Am J Transplant 2015;15:1003-1013. doi:10.1111/ajt.13153.

[41] Clerkin KJ, Farr MA, Restaino SW, Zorn E, Latif F, Vasilescu ER, et al. Donor-specific anti-hla antibodies with antibody-mediated rejection and long-term outcomes following heart transplantation. J Heart Lung Transplant 2017;36:540-545. doi:10.1016/j.healun.2016.10.016.

[42] Barten MJ, Zuckermann A. The meaning of donor-specific antibodies after heart transplant. Curr Opin Organ Transplant 2019;24(3):252258. doi:10.1097/MOT.0000000000000641.

[43] Banasik M, Boratynska M, Koscielska-Kasprzak K, Mazanowska O, Krajewska M, Zabinska M, et al. The impact of de novo donor-specific anti-human leukocyte antigen antibodies on 5-year renal transplant outcome. Transplant Proc 2013;45:1449-1452. doi:10.1016/j. transproceed.2012.12.026.

[44] Hill GS, Nochy D, Bruneval P, Duong van Huyen JP, Glotz D, Suberbielle $\mathrm{C}$, et al. Donor-specific antibodies accelerate arteriosclerosis after kidney transplantation. J Am Soc Nephrol 2011;22:975-983. doi:10.1681/ASN.2010070777.

[45] Ueno T, Zenitani M, Yamanaka H, Tanaka N, Uehara S, Tazuke Y, et al. Impact of donor-specific antibodies on graft fibrosis after pediatric living donor liver transplantation for biliary atresia. Transplant Proc 2016;48:1095-1099. doi:10.1016/j.transproceed.2016.02.011.

[46] Kivela JM, Kosola S, Perasaari J, Makisalo H, Jalanko H, Holmberg C, et al. Donor-specific antibodies after pediatric liver transplantation: A cross-sectional study of 50 patients. Transpl Int 2016;29:494-505. doi:10.1111/tri.12747.

[47] de Kort H, Willicombe M, Brookes P, Dominy KM, Santos-Nunez E, Galliford JW, et al. Microcirculation inflammation associates with outcome in renal transplant patients with de novo donor-specific antibodies. Am J Transplant 2013;13:485-492. doi:10.1111/j.16006143.2012.04325.x.

[48] Del Bello A, Congy-Jolivet N, Muscari F, Lavayssiere L, Esposito L, Cardeau-Desangles I, et al. Prevalence, incidence and risk factors for donor-specific anti-hla antibodies in maintenance liver transplant patients. Am J Transplant 2014;14:867-875. doi:10.1111/ajt.12651.

[49] Miyagawa-Hayashino A, Yoshizawa A, Uchida Y, Egawa H, Yurugi K, Masuda $S$, et al. Progressive graft fibrosis and donor-specific human leukocyte antigen antibodies in pediatric late liver allografts. Liver Transpl 2012;18:1333-1342. doi:10.1002/lt.23534.

[50] Kasahara M, Kiuchi T, Takakura K, Uryuhara K, Egawa H, Asonuma K, et al. Postoperative flow cytometry crossmatch in living donor liver transplantation: Clinical significance of humoral immunity in acute rejection. Transplantation 1999;67:568-575. doi:10.1097/00007890199902270-00014.

[51] Lee PC, Zhu L, Terasaki PI, Everly MJ. Hla-specific antibodies developed in the first year posttransplant are predictive of chronic rejection and renal graft loss. Transplantation 2009;88:568-574. doi:10.1097/TP.0b013e3181b11b72.

[52] Everly MJ. Donor-specific anti-hla antibody monitoring and removal in solid organ transplant recipients. Clin Transpl 2011:319-325.

[53] Cuadrado A, San Segundo D, Lopez-Hoyos M, Crespo J, Fabrega E. Clinical significance of donor-specific human leukocyte antigen antibodies in liver transplantation. World J Gastroenterol
2015;21:11016-11026. doi:10.3748/wjg.v21.i39.11016.

[54] Matsuda Y, Sarwal MM. Unraveling the role of allo-antibodies and transplant injury. Front Immunol 2016;7:432. doi:10.3389/fimmu.2016.00432.

[55] Baldwin WM 3rd, Valujskikh A, Fairchild RL. Mechanisms of antibody-mediated acute and chronic rejection of kidney allografts. Curr Opin Organ Transplant 2016;21:7-14. doi:10.1097/ MOT.0000000000000262.

[56] Piotti G, Palmisano A, Maggiore U, Buzio C. Vascular endothelium as a target of immune response in renal transplant rejection. Front Immunol 2014;5:505. doi:10.3389/fimmu.2014.00505.

[57] Hanf W, Bonder CS, Coates PT. Transplant glomerulopathy: The interaction of hla antibodies and endothelium. J Immunol Res 2014;2014:549315. doi:10.1155/2014/549315.

[58] Valenzuela NM, McNamara JT, Reed EF. Antibody-mediated graft injury: Complement-dependent and complement-independent mechanisms. Curr Opin Organ Transplant 2014;19:33-40. doi:10.1097/ MOT.0000000000000040.

[59] Frank R, Molina MR, Goldberg LR, Wald JW, Kamoun M, Lal P. Circulating donor-specific anti-human leukocyte antigen antibodies and complement c4d deposition are associated with the development of cardiac allograft vasculopathy. Am J Clin Pathol 2014;142:809-815. doi:10.1309/AJCPTLBEU5BQ8SHN.

[60] Legris T, Picard C, Todorova D, Lyonnet L, Laporte C, Dumoulin C, et al. Antibody-dependent $n k$ cell activation is associated with late kidney allograft dysfunction and the complement-independent alloreactive potential of donor-specific antibodies. Front Immunol 2016;7:288. doi:10.3389/fimmu.2016.00288.

[61] Crespo M, Yelamos J, Redondo D, Muntasell A, Perez-Saez MJ, LopezMontanes $\mathrm{M}$, et al. Circulating nk-cell subsets in renal allograft recipients with anti-hla donor-specific antibodies. Am J Transplant 2015;15:806-814. doi:10.1111/ajt.13010.

[62] Diebolder CA, Beurskens FJ, de Jong RN, Koning RI, Strumane K, Lindorfer MA, et al. Complement is activated by igg hexamers assembled at the cell surface. Science 2014;343:1260-1263. doi:10.1126/ science.1248943.

[63] Yabu JM, Higgins JP, Chen G, Sequeira F, Busque S, Tyan DB. C1qfixing human leukocyte antigen antibodies are specific for predicting transplant glomerulopathy and late graft failure after kidney transplantation. Transplantation 2011;91:342-347. doi:10.1097/ TP.0b013e318203fd26.

[64] Sutherland SM, Chen G, Sequeira FA, Lou CD, Alexander SR, Tyan DB. Complement-fixing donor-specific antibodies identified by a novel c1q assay are associated with allograft loss. Pediatr Transplant 2012;16:12-17. doi:10.1111/j.1399-3046.2011.01599.x.

[65] Thammanichanond D, Mongkolsuk T, Rattanasiri S, Kantachuvesiri S, Worawichawong S, Jirasiritham S, et al. Significance of c1q-fixing donor-specific antibodies after kidney transplantation. Transplant Proc 2014;46:368-371. doi:10.1016/j.transproceed.2013.11.011.

[66] Loupy A, Lefaucheur C, Vernerey D, Prugger C, Duong van Huyen JP, Mooney $\mathrm{N}$, et al. Complement-binding anti-hla antibodies and kidney-allograft survival. N Engl J Med 2013;369:1215-1226. doi:10.1056/NEJMoa1302506.

[67] Viglietti D, Bouatou Y, Kheav VD, Aubert O, Suberbielle-Boissel C, Glotz D, et al. Complement-binding anti-hla antibodies are independent predictors of response to treatment in kidney recipients with antibody-mediated rejection. Kidney Int 2018;94:773-787. doi:10.1016/j.kint.2018.03.015.

[68] Bamoulid J, Roodenburg A, Staeck O, Wu K, Rudolph B, Brakemeier S, et al. Clinical outcome of patients with de novo c1q-binding donorspecific hla antibodies after renal transplantation. Transplantation 2017;101:2165-2174. doi:10.1097/TP.0000000000001487.

[69] Racusen LC, Colvin RB, Solez K, Mihatsch MJ, Halloran PF, Campbell $\mathrm{PM}$, et al. Antibody-mediated rejection criteria - an addition to the banff 97 classification of renal allograft rejection. Am J Transplant 2003;3:708-714. doi:10.1034/j.1600-6143.2003.00072.x.

[70] Djamali A, Muth BL, Ellis TM, Mohamed M, Fernandez LA, Miller KM, et al. Increased c4d in post-reperfusion biopsies and increased donor specific antibodies at one-week post transplant are risk factors for acute rejection in mild to moderately sensitized kidney transplant recipients. Kidney Int 2013;83:1185-1192. doi:10.1038/ki.2013.44. 
[71] Hayde N, Bao Y, Pullman J, Ye B, Calder RB, Chung M, et al. The clinical and genomic significance of donor-specific antibody-positive/c4dnegative and donor-specific antibody-negative/c4d-negative transplant glomerulopathy. Clin J Am Soc Nephrol 2013;8:2141-2148. doi:10.2215/CJN.04240413.

[72] Loupy A, Hill GS, Suberbielle C, Charron D, Anglicheau D, Zuber J, et al. Significance of c4d banff scores in early protocol biopsies of kidney transplant recipients with preformed donor-specific antibodies (dsa). Am J Transplant 2011;11:56-65. doi:10.1111/j.16006143.2010.03364.x.

[73] Sis B, Mengel M, Haas M, Colvin RB, Halloran PF, Racusen LC, et al. Banff '09 meeting report: Antibody mediated graft deterioration and implementation of banff working groups. Am J Transplant 2010;10:464-471. doi:10.1111/j.1600-6143.2009.02987.x.

[74] Colvin RB, Smith RN. Antibody-mediated organ-allograft rejection. Nat Rev Immunol 2005;5:807-817. doi:10.1038/nri1702.

[75] Rajalingam R. The impact of hla class i-specific killer cell immunoglobulin-like receptors on antibody-dependent natural killer cellmediated cytotoxicity and organ allograft rejection. Front Immunol 2016;7:585. doi:10.3389/fimmu.2016.00585.

[76] Montgomery RA, Cozzi E, West LJ, Warren DS. Humoral immunity and antibody-mediated rejection in solid organ transplantation. Semin Immunol 2011;23:224-234. doi:10.1016/j.smim.2011.08.021.

[77] Martin L, Guignier F, Bocrie O, D'Athis P, Rageot D, Rifle G, et al. Detection of anti-hla antibodies with flow cytometry in needle core biopsies of renal transplants recipients with chronic allograft nephropathy. Transplantation 2005;79:1459-1461. doi:10.1097/01. TP.0000156164.54216.DE.

[78] Alberu J, Vargas-Rojas MI, Morales-Buenrostro LE, Crispin JC, Rodriguez-Romo $\mathrm{R}$, Uribe-Uribe NO, et al. De novo donor-specific hla antibody development and peripheral cd4(+)cd25(high) cells in kidney transplant recipients: A place for interaction? J Transplant 2012;2012:302539. doi:10.1155/2012/302539.

[79] Zhang C, Shan J, Lu J, Huang Y, Feng L, Long D, et al. Rapamycin in combination with donor-specific cd4+cd25+treg cells amplified in vitro might be realize the immune tolerance in clinical organ transplantation. Cell Immunol 2010;264:111-113. doi:10.1016/j.cellimm.2010.05.014.

[80] Patel R, Terasaki PI. Significance of the positive crossmatch test in kidney transplantation. N Engl J Med 1969;280:735-739. doi:10.1056/ NEJM196904032801401.

[81] Gebel HM, Bray RA. Hla antibody detection with solid phase assays: Great expectations or expectations too great? Am J Transplant 2014;14:1964-1975. doi:10.1111/ajt.12807.

[82] Lachmann N, Todorova K, Schulze H, Schonemann C. Luminex((r)) and its applications for solid organ transplantation, hematopoietic stem cell transplantation, and transfusion. Transfus Med Hemother 2013;40:182-189. doi:10.1159/000351459.

[83] Susal C, Opelz G, Morath C. Role and value of luminex((r))-detected hla antibodies before and after kidney transplantation. Transfus Med Hemother 2013;40:190-195. doi:10.1159/000351314.

[84] Szatmary P, Jones J, Hammad A, Middleton D. Impact of sensitivity of human leucocyte antigen antibody detection by luminex technology on graft loss at 1 year. Clin Kidney J 2013;6:283-286. doi:10.1093/ $\mathrm{ckj} / \mathrm{sft} 037$.

[85] Dieplinger G, Ditt V, Arns W, Huppertz A, Kisner T, Hellmich M, et al. Impact of de novo donor-specific hla antibodies detected by luminex solid-phase assay after transplantation in a group of 88 consecutive living-donor renal transplantations. Transpl Int 2014;27:60-68. doi:10.1111/tri.12207.

[86] Brugiere O, Suberbielle C, Thabut G, Lhuillier E, Dauriat G, Metivier $\mathrm{AC}$, et al. Lung transplantation in patients with pretransplantation donor-specific antibodies detected by luminex assay. Transplantation 2013;95:761-765. doi:10.1097/TP.0b013e31827afb0f.

[87] Nguyen HT, Lim WH, Craig JC, Chapman JR, Lord SJ, Howard K, et al. The relative benefits and costs of solid phase bead technology to detect preformed donor specific antihuman leukocyte antigen antibodies in determining suitability for kidney transplantation. Transplantation 2015;99:957-964. doi:10.1097/TP.0000000000000697.

[88] Tagliamacco A, Cioni M, Comoli P, Ramondetta M, Brambilla C, Trivelli $A$, et al. Dq molecules are the principal stimulators of de novo donor- specific antibodies in nonsensitized pediatric recipients receiving a first kidney transplant. Transpl Int 2014;27:667-673. doi:10.1111/ tri.12316.

[89] Yousem SA, Zeevi A. The histopathology of lung allograft dysfunc tion associated with the development of donor-specific hla alloantibodies. Am J Surg Pathol 2012;36:987-992. doi:10.1097/ PAS.0b013e31825197ae.

[90] Fidler SJ, Irish AB, Lim W, Ferrari P, Witt CS, Christiansen FT. Pre-transplant donor specific anti-hla antibody is associated with antibodymediated rejection, progressive graft dysfunction and patient death. Transpl Immunol 2013;28:148-153. doi:10.1016/j.trim.2013.05.001.

[91] Yamanaga S, Watarai Y, Yamamoto T, Tsujita M, Hiramitsu T, Nanmoku $\mathrm{K}$, et al. Frequent development of subclinical chronic antibodymediated rejection within 1 year after renal transplantation with pre-transplant positive donor-specific antibodies and negative cdc crossmatches. Hum Immunol 2013;74:1111-1118. doi:10.1016/j. humimm.2013.06.022.

[92] Abu-Elmagd KM, Wu G, Costa G, Lunz J, Martin L, Koritsky DA, et al. Preformed and de novo donor specific antibodies in visceral transplantation: Long-term outcome with special reference to the liver. Am J Transplant 2012;12:3047-3060. doi:10.1111/j.16006143.2012.04237.x.

[93] Ntokou IS, Iniotaki AG, Kontou EN, Darema MN, Apostolaki MD, Kostakis AG, et al. Long-term follow up for anti-hla donor specific antibodies postrenal transplantation: High immunogenicity of hla class ii graft molecules. Transpl Int 2011;24:1084-1093. doi:10.1111/j.14322277.2011.01312.x.

[94] Wiebe C, Pochinco D, Blydt-Hansen TD, Ho J, Birk PE, Karpinski M, et al. Class ii hla epitope matching-a strategy to minimize de novo donor-specific antibody development and improve outcomes. Am J Transplant 2013;13:3114-3122. doi:10.1111/ajt.12478.

[95] Freitas MC, Rebellato LM, Ozawa M, Nguyen A, Sasaki N, Everly M, et al. The role of immunoglobulin-g subclasses and c1q in de novo hladq donor-specific antibody kidney transplantation outcomes. Transplantation 2013;95:1113-1119. doi:10.1097/TP.0b013e3182888db6.

[96] DeVos JM, Gaber AO, Knight RJ, Land GA, Suki WN, Gaber LW, et al. Donor-specific hla-dq antibodies may contribute to poor graft outcome after renal transplantation. Kidney Int 2012;82:598-604. doi:10.1038/ki.2012.190.

[97] Omrani O, Alawwami M, Buraiki J, Selimovic N. Donor-specific hladq antibodies may contribute to poor graft outcome after heart transplantation. Ann Saudi Med 2018;38:97-104. doi:10.5144/02564947.2018.97.

[98] Wozniak LJ, Hickey MJ, Venick RS, Vargas JH, Farmer DG, Busuttil RW, et al. Donor-specific hla antibodies are associated with late allograft dysfunction after pediatric liver transplantation. Transplantation 2015;99:1416-1422. doi:10.1097/TP.0000000000000796.

[99] Aubert O, Bories MC, Suberbielle C, Snanoudj R, Anglicheau D, Rabant $M$, et al. Risk of antibody-mediated rejection in kidney trans plant recipients with anti-hla-c donor-specific antibodies. Am J Transplant 2014;14:1439-1445. doi:10.1111/ajt.12709.

[100] Bachelet T, Martinez C, Del Bello A, Couzi L, Kejji S, Guidicelli G, et al. Deleterious impact of donor-specific anti-hla antibodies toward hla-cw and hla-dp in kidney transplantation. Transplantation 2016;100:159-166. doi:10.1097/TP.0000000000000821.

[101] O'Leary JG, Kaneku H, Susskind BM, Jennings LW, Neri MA, Davis $\mathrm{GL}$, et al. High mean fluorescence intensity donor-specific anti-hla antibodies associated with chronic rejection postliver transplant. Am J Transplant 2011;11:1868-1876. doi:10.1111/j.16006143.2011.03593.x.

[102] Kozlowski T, Rubinas T, Nickeleit V, Woosley J, Schmitz J, Collins D, et al. Liver allograft antibody-mediated rejection with demonstration of sinusoidal c4d staining and circulating donor-specific antibodies. Liver Transpl 2011;17:357-368. doi:10.1002/It.22233.

[103] McCaughan JA, Robertson V, Falconer SJ, Cryer C, Turner DM, Oniscu GC. Preformed donor-specific hla antibodies are associated with increased risk of early mortality after liver transplantation. Clin Transplant 2016;30:1538-1544. doi:10.1111/ctr.12851.

[104] Tang MY, Wang QH, Wang J, Gao X, Wu L, Tan JM. Strength of donor-specific antibodies with the use of luminex single-antigen beads is a reliable predictor of acute rejection in living-relative kidney re- 
cipients. Transplant Proc 2015;47:309-312. doi:10.1016/j.transproceed.2014.11.039.

[105] Lefaucheur C, Loupy A, Hill GS, Andrade J, Nochy D, Antoine C, et al. Preexisting donor-specific hla antibodies predict outcome in kidney transplantation. J Am Soc Nephrol 2010;21:1398-1406. doi:10.1681/ ASN.2009101065.

[106] Aubert V, Venetz JP, Pantaleo G, Pascual M. Low levels of human leukocyte antigen donor-specific antibodies detected by solid phase assay before transplantation are frequently clinically irrelevant. Hum Immunol 2009;70:580-583. doi:10.1016/j.humimm.2009.04.011.

[107] Vlad G, Ho EK, Vasilescu ER, Colovai Al, Stokes MB, Markowitz GS, et al. Relevance of different antibody detection methods for the prediction of antibody-mediated rejection and deceased-donor kidney allograft survival. Hum Immunol 2009;70:589-594. doi:10.1016/j. humimm.2009.04.018.

[108] Amico P, Honger G, Mayr M, Steiger J, Hopfer H, Schaub S. Clinical relevance of pretransplant donor-specific hla antibodies detected by single-antigen flow-beads. Transplantation 2009;87:1681-1688. doi:10.1097/TP.0b013e3181a5e034.

[109] Adebiyi OO, Gralla J, Klem P, Freed B, Davis S, Wiseman AC, et al. Clinical significance of pretransplant donor-specific antibodies in the setting of negative cell-based flow cytometry crossmatching in kidney transplant recipients. Am J Transplant 2016;16:3458-3467. doi:10.1111/ajt.13848.

[110] Yoo PS, Bonnel A, Kamoun M, Levine MH. Clinical outcomes among renal transplant recipients with pre-transplant weakly reactive donor-specific antibodies. Clin Transplant 2014;28:127-133. doi:10.1111/ctr.12289.

[111] Heilman RL, Nijim A, Desmarteau YM, Khamash H, Pando MJ, Smith $\mathrm{ML}$, et al. De novo donor-specific human leukocyte antigen antibodies early after kidney transplantation. Transplantation 2014;98:1310 1315. doi:10.1097/TP.0000000000000216.

[112] Ushigome H, Harada S, Nakao M, Nakamura T, Koshino K, Suzuki $\mathrm{T}$, et al. Living-donor kidney transplantation with existing anti-donor specific antibodies at a japanese single center. Transplant Proc 2015;47:612-616. doi:10.1016/j.transproceed.2014.12.039.

[113] Jordan SC, Choi J, Vo A. Achieving incompatible transplantation through desensitization: Current perspectives and future directions. Immunotherapy 2015;7:377-398. doi:10.2217/imt.15.10.

[114] Macklin PS, Morris PJ, Knight SR. A systematic review of the use of rituximab for desensitization in renal transplantation. Transplantation 2014;98:794-805. doi:10.1097/TP.0000000000000362.

[115] Zachary AA, Leffell MS. Desensitization for solid organ and hematopoietic stem cell transplantation. Immunol Rev 2014;258:183-207. doi:10.1111/imr.12150.

[116] Jordan SC, Reinsmoen N, Lai CH, Vo A. Novel immunotherapeutic approaches to improve rates and outcomes of transplantation in sensitized renal allograft recipients. Discov Med 2012;13:235-245.

[117] Sadaka B, Alloway RR, Woodle ES. Clinical and investigational use of proteasome inhibitors for transplant rejection. Expert Opin Investig Drugs 2011;20:1535-1542. doi:10.1517/13543784.2011.618494.

[118] Jackups R Jr, Canter C, Sweet SC, Mohanakumar T, Morris GP. Measurement of donor-specific hla antibodies following plasma exchange therapy predicts clinical outcome in pediatric heart and lung transplant recipients with antibody-mediated rejection. J Clin Apher 2013;28:301-308. doi:10.1002/jca.21270.

[119] Stegall MD, Gloor J, Winters JL, Moore SB, Degoey S. A comparison of plasmapheresis versus high-dose ivig desensitization in renal allograft recipients with high levels of donor specific alloantibody. Am J Transplant 2006;6:346-351. doi:10.1111/j.1600-6143.2005.01178.x.

[120] Yamada C, Ramon DS, Cascalho M, Sung RS, Leichtman AB, Samaniego $\mathrm{M}$, et al. Efficacy of plasmapheresis on donor-specific antibody reduction by hla specificity in post-kidney transplant recipients. Transfusion 2015;55(4):727-735. doi:10.1111/trf.12923.

[121] O'Leary JG, Samaniego M, Barrio MC, Potena L, Zeevi A, Djamali $A$, et al. The influence of immunosuppressive agents on the risk of de novo donor-specific hla antibody production in solid organ transplant recipients. Transplantation 2016;100:39-53. doi:10.1097/ TP.0000000000000869.

[122] Pizzo HP, Ettenger RB, Gjertson DW, Reed EF, Zhang J, Gritsch HA, et al. Sirolimus and tacrolimus coefficient of variation is associated with rejection, donor-specific antibodies, and nonadherence. Pediatr Nephrol 2016;31:2345-2352. doi:10.1007/s00467-016-3422-5.

[123] Rodrigo E, Segundo DS, Fernandez-Fresnedo G, Lopez-Hoyos M, Benito A, Ruiz JC, et al. Within-patient variability in tacrolimus blood levels predicts kidney graft loss and donor-specific antibody development. Transplantation 2016;100:2479-2485. doi:10.1097/ TP.0000000000001040.

[124] Filler G, Todorova EK, Bax K, Alvarez-Elias AC, Huang SH, Kobrzynski MC. Minimum mycophenolic acid levels are associated with donorspecific antibody formation. Pediatr Transplant 2016;20:34-38. doi:10.1111/petr.12637.

[125] Croze LE, Tetaz R, Roustit M, Malvezzi P, Janbon B, Jouve T, et al. Conversion to mammalian target of rapamycin inhibitors increases risk of de novo donor-specific antibodies. Transpl Int 2014;27:775783. doi:10.1111/tri.12330.

[126] Kamar N, Del Bello A, Congy-Jolivet N, Guilbeau-Frugier C, Cardeau-Desangles I, Fort $\mathrm{M}$, et al. Incidence of donor-specific antibodies in kidney transplant patients following conversion to an everolimus-based calcineurin inhibitor-free regimen. Clin Transplant 2013;27:455-462. doi:10.1111/ctr.12127.

[127] Liefeldt L, Brakemeier S, Glander P, Waiser J, Lachmann N, Schonemann $C$, et al. Donor-specific hla antibodies in a cohort comparing everolimus with cyclosporine after kidney transplantation. Am J Transplant 2012;12:1192-1198. doi:10.1111/j.1600-6143.2011.03961.x.

[128] Jackson AM, Kraus ES, Orandi BJ, Segev DL, Montgomery RA, Zachary AA. A closer look at rituximab induction on hla antibody rebound following hla-incompatible kidney transplantation. Kidney Int 2015;87:409-416. doi:10.1038/ki.2014.261.

[129] Shaffer D, Feurer ID, Crowe D, Schaefer H. Early and sustained reduction in donor-specific antibodies in desensitized living donor kidney transplant recipients: A 3-year prospective study. Transplant Direct 2016;2:e62. doi:10.1097/TXD.0000000000000570.

[130] Ius F, Sommer W, Kieneke D, Tudorache I, Kuhn C, Avsar M, et al. Igm-enriched human intravenous immunoglobulin-based treatment of patients with early donor specific anti-hla antibodies after lung transplantation. Transplantation 2016;100:2682-2692. doi:10.1097/ TP.0000000000001027.

[131] Morrow WR, Frazier EA, Mahle WT, Harville TO, Pye SE, Knecht $\mathrm{KR}$, et al. Rapid reduction in donor-specific anti-human leukocyte antigen antibodies and reversal of antibody-mediated rejection with bortezomib in pediatric heart transplant patients. Transplantation 2012;93:319-324. doi:10.1097/TP.0b013e31823f7eea.

[132] Everly MJ, Terasaki PI, Trivedi HL. Durability of antibody removal following proteasome inhibitor-based therapy. Transplantation 2012;93:572-577. doi:10.1097/TP.0b013e31824612df.

[133] Woodle ES, Shields AR, Ejaz NS, Sadaka B, Girnita A, Walsh RC, et al. Prospective iterative trial of proteasome inhibitor-based desensitization. Am J Transplant 2015;15:101-118. doi:10.1111/ajt.13050.

[134] Guthoff M, Schmid-Horch B, Weisel KC, Haring HU, Konigsrainer A, Heyne N. Proteasome inhibition by bortezomib: Effect on hlaantibody levels and specificity in sensitized patients awaiting renal allograft transplantation. Transpl Immunol 2012;26:171-175. doi:10.1016/j.trim.2012.01.002.

[135] Todeschini M, Cortinovis M, Perico N, Poli F, Innocente A, Cavinato RA, et al. In kidney transplant patients, alemtuzumab but not basiliximab/low-dose rabbit anti-thymocyte globulin induces $b$ cell depletion and regeneration, which associates with a high incidence of de novo donor-specific anti-hla antibody development. J Immunol 2013;191:2818-2828. doi:10.4049/jimmunol.1203261.

[136] Kwun J, Page E, Hong JJ, Gibby A, Yoon J, Farris AB, et al. Neutralizing baff/april with atacicept prevents early dsa formation and amr development in $\mathrm{t}$ cell depletion induced nonhuman primate amr model. Am J Transplant 2015;15:815-822. doi:10.1111/ajt.13045.

[137] Ford ML, Adams AB, Pearson TC. Targeting co-stimulatory pathways: Transplantation and autoimmunity. Nat Rev Nephrol 2014;10:14-24. doi:10.1038/nrneph.2013.183.

[138] Broin PO, Hayde N, Bao Y, Ye B, Calder RB, de Boccardo G, et al. A pathogenesis-based transcript signature in donor-specific antibodypositive kidney transplant patients with normal biopsies. Genom Data 2014;2:357-360. doi:10.1016/j.gdata.2014.10.005.

[139] Eskandary F, Bond G, Kozakowski N, Regele H, Marinova L, Wah- 
rmann $\mathrm{M}$, et al. Diagnostic contribution of donor-specific antibody characteristics to uncover late silent antibody-mediated rejection-results of a cross-sectional screening study. Transplantation 2017;101:631-641. doi:10.1097/TP.0000000000001195.

[140] Hoshino J, Kaneku H, Everly MJ, Greenland S, Terasaki PI. Using donor-specific antibodies to monitor the need for immunosuppression. Transplantation 2012;93:1173-1178. doi:10.1097/ TP.0b013e31824f3d7c.

[141] Del Bello A, Congy-Jolivet N, Danjoux M, Muscari F, Kamar N. Donor-specific antibodies and liver transplantation. Hum Immunol 2016;77:1063-1070. doi:10.1016/j.humimm.2016.02.006.

[142] In JW, Park H, Rho EY, Shin S, Park KU, Park MH, et al. Anti-angiotensin type 1 receptor antibodies associated with antibody-me- diated rejection in patients without preformed hla-donor-specific antibody. Transplant Proc 2014;46:3371-3374. doi:10.1016/j. transproceed.2014.09.096.

[143] Fuss A, Hope CM, Deayton S, Bennett GD, Holdsworth R, Carroll $\mathrm{RP}$, et al. C4d-negative antibody-mediated rejection with high antiangiotensin ii type i receptor antibodies in absence of donor-specific antibodies. Nephrology (Carlton) 2015;20:467-473. doi:10.1111/ nep.12441.

[144] Lee J, Park Y, Kim BS, Lee JG, Kim HJ, Kim YS, et al. Clinical implications of angiotensin ii type 1 receptor antibodies in antibodymediated rejection without detectable donor-specific hla antibodies after renal transplantation. Transplant Proc 2015;47:649-652. doi:10.1016/j.transproceed.2014.11.055. 